\title{
Quality characteristics of noodles made from selected varieties of Sri Lankan rice with different physicochemical characteristics
}

\author{
M.J.M. Fari ${ }^{1 *}$, D. Rajapaksa ${ }^{1}$ and K.K.D.S. Ranaweera ${ }^{2}$ \\ ${ }^{1}$ Food Technology Section, Industrial Technology Institute, 363, Bauddhaloka Mawatha, Colombo 07. \\ ${ }^{2}$ Department of Food Science \& Technology, Faculty of Applied Sciences, University of Sri Jayewardenepura, Gangodawila, Nugegoda.
}

Revised: 27 September 2010 ; Accepted: 26 November 2010

\begin{abstract}
The physicochemical properties of eight popular Sri Lankan rice varieties (Bg 300, Bg 352, Bg 403, Bg 94-1, Ld 356, Bw 272-6b, At 405 and At 306) and the quality characteristics of noodles made from these varieties of rice were investigated. The physicochemical properties investigated were amylose content (AC), crude protein, fat content, starch properties and amylograph pasting properties. Rice noodles were prepared by gelatinization of dough made with rice flour followed by cold extrusion. Rice noodle samples were evaluated for cooking loss, swelling ratio, tensile strength, extensibility, elastic recovery, firmness and sensory properties. AC of rice varieties ranged from $18.65 \pm 1.19 \%$ in At 405 to $30.43 \pm 0.20 \%$ in Bg 94-1. Swelling volume and swelling power were significantly different $(\mathrm{p}<0.05)$ among the rice varieties tested. Amylograph pasting properties of rice varieties showed a significant $(p<0.05)$ variation for all the pasting parameters. Cooking loss was high in At 405 (19.17 \pm 3.50$)$, and low in $\mathrm{Bg} 403$ (9.19 \pm 0.33$)$. Tensile strength was significantly high for $\mathrm{Bg} 352(16.7 \pm 3.4 \mathrm{~g})$ and it was significantly low for At $405(8.0 \pm 1.7 \mathrm{~g})$. Overall acceptability of rice noodles prepared from At 405 had the significantly lower score and rice noodles from $\mathrm{Bg} 300$ had a significantly higher value. The physicochemical and amylograph pasting properties of rice varieties had a significant influence on the cooking, textural and sensory properties of rice noodles. Amylose content showed significant negative correlation with cooking loss $(\mathrm{r}=-0.802, \mathrm{p}<0.001)$ and significant positive correlation with swelling ratio $(\mathrm{r}=0.809, \mathrm{p}<0.001)$ of noodles. Amylose content showed positive significant correlation with tensile strength, extensibility and elastic recovery at $\mathrm{p}<0.05$. Rice noodles made from local rice varieties with high amylose content showed desirable quality characteristics.
\end{abstract}

Keywords: Amylose, amylograph viscosity, cooking property, noodles, rice, textural quality.

\section{INTRODUCTION}

Rice (Oryza sativa L.) is the staple food in Sri Lanka and it provides $45 \%$ calorie and $40 \%$ total protein requirement of an average Sri Lankan (Mendis, 2006). More than 50 rice varieties have been recommended for cultivation in Sri Lanka by the Department of Agriculture (DOASL, 2006; Wickramasinghe \& Nado, 2008).

Different rice varieties exhibit compositional variation for protein, lipid, starch content (amylose and amylopectin) and other minerals and vitamins. These compositional differences contribute to the diversity of chemical and physical properties of rice such as viscosity, starch gelatinization and water absorption (Juliano, 1985). These properties influence the eating and cooking quality of rice and have a considerable effect on quality characteristics of end products such as bread, noodles and other extruded products made from rice flour.

Traditionally, rice noodles are made from long grain rice with high amylose content $(>25 \mathrm{~g} / 100 \mathrm{~g})$ (Juliano \& Sakurai, 1985), which plays a critical role in creating a gel network and sets the noodle structure (Mestres et al., 1988). A highly significant correlation was reported between high amylose content of rice and general acceptability of rice noodles (Yoenyongbuddhagal \& Noomhorm, 2002). Bhattacharya et al. (1999) reported that the broad variation in physical and chemical properties of rice had a marked influence on the textural quality of rice noodles. It has been reported that rice noodle characteristics correlated significantly with swelling power (SP), paste viscosities and gel texture of starch present in rice flour (Bhattacharya et al., 1999; Hormdok \& Noomhorm, 2007).

A wide array of rice varieties is present in the country and their physicochemical characteristics vary. When different rice varieties are used for rice noodle 
production, variation in quality characteristics can be expected. A detailed study of the effect of Sri Lankan rice varieties on the quality of rice noodles is not documented to date.

The objectives of the present study were to investigate the physicochemical properties of locally grown rice varieties, the quality characteristics such as cooking, textural and sensory attributes of rice noodles and to determine the relationship between physicochemical characteristics of rice varieties and the quality of noodles made from flour of different varieties of rice.

\section{METHODS AND MATERIALS}

The following paddy samples were collected from Rice Research and Development Centres in Sri Lanka and their respective regional stations; $\mathrm{Bg} 300, \mathrm{Bg} 403$, Bg 94-1 and $\mathrm{Bg} 352$ from Bathalagoda (Bg); At 306 and At 405 from Ambalantota (At); Bw 272-6b from Bombuwala (Bw); and Ld 356 from Labuduwa (Ld).

Preparation of raw materials: The grains were dehulled and polished using a commercial dehuller (Type LM 242C, Rubber roller, China) and a polisher (Model N-70, China) at a commercial grinding mill in Colombo. Rice was ground to make flour using the universal milling machine (Universal mill PE 402, Bauermeister, Germany) fitted with a $0.5 \mathrm{~mm}$ sieve attachment at the Industrial Technology Institute (ITI), Colombo.

Physicochemical analysis: Crude protein (Kjeldhal nitrogen using DK 6 heating digester and Kjeltec semiautomatic distillation unit, UDK 132, VELP Scientifica, Italy) (Nitrogen conversion factor $=5.95$ ) and crude fat (Soxotherm 5306 AK, Gerhardt, Bornheimer Strabecon, Bonn, Germany) were determined according to the AACC method (1995). Amylose content (AC) was determined according to the method of Juliano (1985).

Starch properties: The method of Crosbie et al. (1992) was used to study the starch properties. Flour samples $(0.4 \mathrm{~g} \mathrm{db})$ were mixed with $12.5 \mathrm{~mL}$ water in centrifuge tubes. The mix was equilibrated at $25{ }^{\circ} \mathrm{C}$ for $5 \mathrm{~min}$. It was then heated to $92.5{ }^{\circ} \mathrm{C}$ and kept at that temperature for $30 \mathrm{~min}$. The samples were cooled in an ice water bath for $1 \mathrm{~min}$, equilibrated at $25^{\circ} \mathrm{C}$ for $5 \mathrm{~min}$ and centrifuged (ICE Centra - 4B Centrifuge, Damon, USA) at $3000 \mathrm{rpm}$ for $5 \mathrm{~min}$. The flour swelling volume $(\mathrm{mL} / \mathrm{g})$ was calculated by converting the resultant gels on volume basis.

The supernatant was carefully removed and the swollen starch sediment was weighed. Swelling power (SP) was expressed as the ratio of weight of wet sediment to the initial weight of dry flour $(\mathrm{g} / \mathrm{g})$. The supernatant was placed in the evaporating dish and dried at $130{ }^{\circ} \mathrm{C}$ for $4 \mathrm{~h}$ to get a constant weight. Solubility $(\mathrm{g} / \mathrm{g})$ was estimated as the ratio of the weight of dry flour supernatant to the initial weight of dried flour.

Amylograph pasting properties: Pasting properties of rice samples were studied using the Amylograph (Brabender, BD 172502, Duisburg, Germany) according to the AACC Method (1995). Rice flour (50 g, $12 \%$ moisture basis) was weighed and mixed with $450 \mathrm{~mL}$ of distilled water to get $10 \%(\mathrm{~g} / \mathrm{g})$ slurry. Prepared sample was transferred to a viscometer bowl. The test was started at $35{ }^{\circ} \mathrm{C}$ and held for $5 \mathrm{~min}$, followed by heating to $95^{\circ} \mathrm{C}$ at the rate of $1.5^{\circ} \mathrm{C} / \mathrm{min}$ and kept for $20 \mathrm{~min}$. The sample was then cooled to $50{ }^{\circ} \mathrm{C}$ at the rate of $1.5^{\circ} \mathrm{C} / \mathrm{min}$ while maintaining the rotating speed of bowl at $75 \mathrm{rpm}$. Peak viscosity (PV), viscosity at the end of hold time at $95^{\circ} \mathrm{C} /$ hot paste viscosity (HPV), final viscosity at the end of cooling to $50{ }^{\circ} \mathrm{C} /$ cold paste viscosity $(\mathrm{CPV})$, breakdown $(\mathrm{BD}=\mathrm{PV}-$ $\mathrm{HPV})$ and setback ( $\mathrm{SB}=\mathrm{CPV}-\mathrm{PV})$ were recorded.

Preparation of rice noodles: Noodles were prepared using $1 \mathrm{~kg}$ of rice flour. Rice flour was mixed with water to form a dough in the Hobart mixer (Hobart CE 100, London, UK). The dough was gelatinized by placing in a kitchen steamer and steamed for $30 \mathrm{~min}$. The dough was kneaded for $15 \mathrm{~min}$ to evenly distribute the gelatinized starch. The dough was then placed in a Pasta machine (Pama Roma MODP/ 15, Pama Parsi, Rome, Italy), fitted with a die of $0.1 \mathrm{~cm}$ diameter pore size and extruded to get strands. These strands were steamed for $15 \mathrm{~min}$ and dried at $40{ }^{\circ} \mathrm{C}$ for $4 \mathrm{~h}$ in an electric dryer (Pama Roma MODPR/12, Pama Parsi, Rome, Italy).

Cooking and textural quality of noodles: Dried noodles $(25.0 \mathrm{~g})$ were cut into small pieces $(5.0 \mathrm{~cm}$ in length) and boiled in $250 \mathrm{~mL}$ of water for $5 \mathrm{~min}$ with occasional stirring. The cooking time of noodles was determined by pressing the noodle between two glass plates and disappearance of the white core was examined with naked eyes. Cooking time is the time taken for the white core to disappear when the noodle strand is boiled in water (Chen et al., 2002). Cooked samples were drained for $5 \mathrm{~min}$ and immediately weighed. The drained water was collected and the volume was noted. Twenty millilitres of the drained water was transferred to an evaporating dish and dried at $105{ }^{\circ} \mathrm{C}$ until a constant weight was attained. Cooking loss (\%) was calculated based on the dry weight of noodles (SLS, 1989). Rehydration or swelling ratio was estimated as the percentage increase in weight of cooked noodles compared to weight of dried noodles (Suhendro et al., 2000). 
Testing for tensile strength was carried out using Tensile Tester (Tinius Olsen HIOKS-5698, Red Hill, England) as described by Bhattacharya et al. (1995). A strand of cooked noodles was wound around parallel rollers of the tensile tester. The upper arm was set to travel apart from the lower arm at the speed of $1 \mathrm{~mm} / \mathrm{s}$. The maximum force $(\mathrm{g})$ required to break the noodles gives an indication of the sample's resistance to breakdown, and the distance (mm) to breakdown indicates the extensibility. The experiments were replicated 10 times.

Firmness and elastic recovery were determined according to the methods described by Sowbhagya and Ali (2001). Noodle strands were compressed using a constant load $(50 \mathrm{~N})$ with a Relaxation tester (Elastocon AB, EB 02, Sweden) for $5 \mathrm{~min}$. Load was removed and allowed to recover for $5 \mathrm{~min}$. Thickness measurements were taken before compression, after compression and after recovery. Firmness (F) and elastic recovery (ER) were calculated from the average of readings as follows,

$\mathrm{F}(\%)=\left[\mathrm{e}_{1} / \mathrm{e}\right] * 100$

$\operatorname{ER}(\%)=\left[\left(\mathrm{e}_{2}-\mathrm{e}_{1}\right) /\left(\mathrm{e}-\mathrm{e}_{1}\right)\right]^{*} 100$

where,

$\mathrm{e}=$ thickness of strands $(\mathrm{mm})$ before compression

$\mathrm{e}_{1}=$ thickness of strands $(\mathrm{mm})$ after compression

$\mathrm{e}_{2}=$ thickness of strands $(\mathrm{mm})$ after recovery

Sensory evaluation: The prepared noodles were evaluated by 12 screened and trained panellists at ITI. The sensory quality of noodles was evaluated based on the preference for appearance, flavour, hardness, stickiness and overall acceptability using a 7-point hedonic scale, where 1-represented the least preference and 7-the most preference. Samples were evaluated by the panellists in individual booths. Sample size of $20 \mathrm{~g}$ was served in a

Table 1: Physicochemical properties of rice

\begin{tabular}{lclc}
\hline Variety & $\begin{array}{c}\text { Amylose } \\
(\%)\end{array}$ & $\begin{array}{c}\text { Fat } \\
(\%, \mathrm{db})\end{array}$ & $\begin{array}{c}\text { Protein } \\
(\%, \mathrm{db})\end{array}$ \\
\hline Bg 352 & $28.94 \pm 1.78^{\mathrm{a}, \mathrm{b}}$ & $0.85 \pm 0.06^{\mathrm{e}}$ & $8.40 \pm 0.43^{\mathrm{c}}$ \\
Bg 300 & $26.76 \pm 1.64^{\mathrm{c}}$ & $0.56 \pm 0.09^{\mathrm{f}}$ & $7.84 \pm 0.07^{\mathrm{d}}$ \\
Bg 403 & $29.17 \pm 0.35^{\mathrm{a}, \mathrm{b}}$ & $1.03 \pm 0.05^{\mathrm{c}, \mathrm{d}}$ & $7.34 \pm 0.14^{\mathrm{e}}$ \\
Bg 94-1 & $30.43 \pm 0.20^{\mathrm{a}}$ & $1.36 \pm 0.04^{\mathrm{a}}$ & $6.84 \pm 0.20^{\mathrm{f}}$ \\
Ld 356 & $27.23 \pm 0.81^{\mathrm{b}, \mathrm{c}}$ & $0.75 \pm 0.15^{\mathrm{e}}$ & $11.18 \pm 0.22^{\mathrm{a}}$ \\
Bw 272-6b & $25.51 \pm 1.50^{\mathrm{c}}$ & $1.17 \pm 0.18^{\mathrm{b}, \mathrm{c}}$ & $9.76 \pm 0.03^{\mathrm{b}}$ \\
At 405 & $18.65 \pm 1.19^{\mathrm{d}}$ & $0.89 \pm 0.04^{\mathrm{d}, \mathrm{e}}$ & $8.55 \pm 0.44^{\mathrm{c}}$ \\
At 306 & $25.87 \pm 1.05^{\mathrm{c}}$ & $1.28 \pm 0.10^{\mathrm{a}, \mathrm{b}}$ & $10.02 \pm 0.08^{\mathrm{b}}$ \\
\hline
\end{tabular}

In each column means with same superscript are not significantly different $(\mathrm{p}<0.05)$; $\mathrm{db}=$ dry basis small glass cup coded with three digit random numbers.

Statistical Analysis: Data were analysed by Analysis of Variance (ANOVA) and mean separation was done by Fishers Least Square difference (LCD) at $p<0.05$. The sensory data were subjected to Freidman non-parametric two-way ANOVA using SAS (v. 6.12) package. Pearson correlation coefficients among parameters were calculated using SAS Proc corr (v. 6.12).

\section{RESULTS AND DISCUSSION}

\section{Physicochemical characteristics of rice}

The amylose content of tested varieties of brown rice is given in Table 1. Based on the amylose content (AC), rice can be classified as waxy rice (1-2\%), low amylose rice $(2-20 \%)$, intermediate amylose rice $(20-25 \%)$ and high amylose rice $(>25 \%)$ (Yoenyong-buddhagal \& Noomhorm, 2002). All varieties used in the study belong to high amylose type rice except At 405, which belongs to the low amylose type. Significant differences $(p<0.05)$ were observed among the $\mathrm{AC}$ of the rice varieties studied. Bg 94-1 had significantly higher AC with $30.43 \pm 0.20 \%$.

Fat content of rice ranged from $1.36 \pm 0.03 \%$ for $\mathrm{Bg}$ 94-1 to $0.56 \pm 0.09 \%$ in $\mathrm{Bg} 300$. High amylose type rice tends to have less starch and lipids than the intermediate rice (Bhattacharya et al., 1999). However, the present study does not show any such relationship. The highest and lowest fat contents were observed in high amylose type rice varieties (Table 1). Protein content ranged from $6.84 \pm 0.20 \%$ in Bg 94-1 to $11.18 \pm 0.22 \%$ in Ld 366, which has red pericarp. Protein content was comparatively low in Bathalagoda rice varieties.

Table 2: Starch properties of rice

\begin{tabular}{lccc}
\hline Variety & $\begin{array}{c}\text { Swelling } \\
\text { power }(\mathrm{g} / \mathrm{g})\end{array}$ & $\begin{array}{c}\text { Swelling } \\
\text { volume }(\mathrm{mL} / \mathrm{g})\end{array}$ & $\begin{array}{c}\text { Solubility } \\
(\mathrm{g} / \mathrm{g})\end{array}$ \\
\hline Bg 352 & $8.33 \pm 0.44^{\mathrm{b}}$ & $8.92 \pm 0.73^{\mathrm{b}, \mathrm{c}}$ & $0.012 \pm 0.007^{\mathrm{a}}$ \\
Bg 300 & $8.28 \pm 0.28^{\mathrm{b}}$ & $8.89 \pm 0.23^{\mathrm{b}, \mathrm{c}}$ & $0.007 \pm 0.006^{\mathrm{b}}$ \\
Bg 403 & $7.96 \pm 0.18^{\mathrm{b}, \mathrm{c}}$ & $9.25 \pm 0.22^{\mathrm{b}}$ & $0.012 \pm 0.003^{\mathrm{a}}$ \\
Bg 94-1 & $7.77 \pm 0.14^{\mathrm{b}, \mathrm{c}}$ & $8.49 \pm 0.22^{\mathrm{b}}$ & $0.015 \pm 0.009^{\mathrm{a}}$ \\
Ld 356 & $8.19 \pm 0.29^{\mathrm{b}, \mathrm{c}}$ & $9.29 \pm 0.15^{\mathrm{b}}$ & $0.013 \pm 0.005^{\mathrm{a}}$ \\
Bw 272-6b & $8.92 \pm 0.40^{\mathrm{a}}$ & $10.41 \pm 0.42^{\mathrm{a}}$ & $0.013 \pm 0.003^{\mathrm{a}}$ \\
At 405 & $8.33 \pm 0.28^{\mathrm{b}}$ & $10.18 \pm 0.28^{\mathrm{a}}$ & $0.008 \pm 0.004^{\mathrm{a}}$ \\
At 306 & $8.12 \pm 0.47^{\mathrm{b}, \mathrm{c}}$ & $9.38 \pm 0.40^{\mathrm{b}}$ & $0.013 \pm 0.004^{\mathrm{a}}$ \\
\hline
\end{tabular}

In each column means with same superscript are not significantly different $(\mathrm{p}<0.05)$ 


\section{Starch properties of rice}

When starch is heated in the presence of excess water to temperatures above the gelatinization temperature, the granules imbibe water and swell causing starch to leach into the solution. The degree of swelling and the amount of solubilization depends on the chemical binding within the granules (Zhou et al., 2002). Presence of strong intermolecular bonds and high amylose content reduces the extent of swelling by forming an extensive network. The degree of swelling and level of solubilization also depends on the extent of chemical bonding within the granules (Bhattacharya et al., 1995).

Swelling power indicates the ability of starch to hydrate under a specific cooking condition (92.5 $\left.{ }^{\circ} \mathrm{C} / 30 \mathrm{~min}\right)$. Swelling volume and swelling power were significantly different $(\mathrm{p}<0.05)$ among rice varieties (Table 2). Rice variety $\mathrm{Bg}$ 94-1 showed the lowest swelling power $(7.77 \pm 0.14 \mathrm{~g} / \mathrm{g})$ and swelling volume $(8.49 \pm 0.22 \mathrm{~mL} / \mathrm{g})$, while $\mathrm{Bw} 272-6 \mathrm{~b}$ showed the highest swelling power $(8.92 \pm 0.40 \mathrm{~g} / \mathrm{g})$ and swelling volume $(10.41 \pm 0.42 \mathrm{~mL} / \mathrm{g})$. Starch leaching during gelatinization is estimated by solubility. A significant difference $(\mathrm{p}<0.05)$ was observed for solubility of rice starches and the rice variety Bg 300 had the significantly lowest solubility.

The difference in swelling power may be attributed to the difference in amylose content, viscosity patterns and weak internal organization resulting from negatively charged phosphate groups within the rice starch granules (Sing et al., 2006). Swelling behaviour of cereal starches has been reported as a property of their amylopectin content, where amylose acts as an inhibitor of swelling (Bhattacharya et al., 1995; Sing et al., 2006). This could be the reason for rice variety with low AC (At 405) having a high swelling volume.

\section{Amylograph pasting properties of rice}

Pasting properties are regarded as one of the most important indices in the evaluation of starch properties of rice (Zhou et al., 2002). Paste viscosity profile or gelatinization pattern recorded in Brabender Amylograph for rice varieties showed a significant $(p<0.05)$ variation for all the pasting parameters (Table 3 ).

Peak viscosity (PV) indicates the highest viscosity yield by starch during the gelatinization under given conditions (Shuey \& Tipples, 1994). The PV ranged from $813 \pm 58 \mathrm{BU}$ in At 306 to $1240 \pm 150$ in $\mathrm{Bg} 300$. The high PV of Bg 300 reflects the ability of starch granules to swell freely before their physical breakdown. At 306, which had the lowest PV, indicates lower tendency for swelling of starch granules.

The viscosity measured after 20 minutes at $95{ }^{\circ} \mathrm{C}$ or hot paste viscosity (HPV) gives an indication of the stability of hot paste (Shuey \& Tipples, 1994). HPV is influenced by the rate of amylose exudation, amylose-lipid complex formation, granule swelling and competition between exudated amylose and remaining granules for free water (Bhattacharya et al., 1999). HPV ranged from $576 \pm 159$ in At 406 to $897 \pm 55$ in $\mathrm{Bg} 352$.

Cold paste viscosity (CPV) describes retrogradation tendency of soluble amylose upon cooling (Bhattacharya et al., 1999). CPV increases upon cooling, which may be due to the aggregation of elements present in the hot paste such as swollen granules, fragments of swollen granules and starch molecules dispersed as colloids (Sing et al., 2006; Shuey \& Tipples, 1994). CPV of rice samples ranged from $762 \pm 161 \mathrm{BU}$ in At 405 to $2137 \pm 185 \mathrm{BU}$ in Bg 352 .

Table 3: Amylograph pasting properties of rice

\begin{tabular}{lccccc}
\hline Variety & $\begin{array}{c}\text { Peak } \\
\text { viscosity } \\
(\mathrm{PV})(\mathrm{BU})\end{array}$ & $\begin{array}{c}\text { Hot paste } \\
\text { viscosity } \\
(\mathrm{HPV})(\mathrm{BU})\end{array}$ & $\begin{array}{c}\text { Cold paste } \\
\text { viscosity } \\
(\mathrm{CPV})(\mathrm{BU})\end{array}$ & $\begin{array}{c}\text { Set back } \\
(\mathrm{SB})(\mathrm{BU})\end{array}$ & $\begin{array}{c}\text { Breakdown } \\
(\mathrm{BD})(\mathrm{BU})\end{array}$ \\
\hline Bg 352 & $1193 \pm 31^{\mathrm{a}}$ & $897 \pm 55^{\mathrm{a}}$ & $2137 \pm 185^{\mathrm{a}}$ & $943 \pm 162^{\mathrm{a}}$ & $297 \pm 55^{\mathrm{b} \cdot \mathrm{c}}$ \\
Bg 300 & $1240 \pm 150^{\mathrm{a}}$ & $770 \pm 125^{\mathrm{a}, \mathrm{b}}$ & $1620 \pm 231^{\mathrm{b}}$ & $380 \pm 87^{\mathrm{c}, \mathrm{d}, \mathrm{e}}$ & $470 \pm 36^{\mathrm{a}, \mathrm{b}}$ \\
Bg 403 & $1230 \pm 26^{\mathrm{a}}$ & $653 \pm 91^{\mathrm{b}, \mathrm{c}}$ & $1420 \pm 30^{\mathrm{b}}$ & $190 \pm 20^{\mathrm{d}, \mathrm{e}}$ & $577 \pm 115^{\mathrm{a}}$ \\
Bg 94-1 & $1203 \pm 60^{\mathrm{a}}$ & $647 \pm 93^{\mathrm{b}, \mathrm{c}}$ & $1373 \pm 108^{\mathrm{b}}$ & $170 \pm 53^{\mathrm{e}}$ & $557 \pm 119^{\mathrm{a}}$ \\
Ld 356 & $1133 \pm 70^{\mathrm{a}}$ & $850 \pm 56^{\mathrm{a}}$ & $1570 \pm 262^{\mathrm{b}}$ & $437 \pm 225^{\mathrm{c}, \mathrm{d}}$ & $283 \pm 68^{\mathrm{b}, \mathrm{c}}$ \\
Bw 272-6b & $1177 \pm 236^{\mathrm{a}}$ & $867 \pm 99^{\mathrm{a}}$ & $1987 \pm 273^{\mathrm{a}}$ & $810 \pm 270^{\mathrm{a}, \mathrm{b}}$ & $310 \pm 257^{\mathrm{b}, \mathrm{c}}$ \\
At 405 & $1030 \pm 204^{\mathrm{a}, \mathrm{b}}$ & $576 \pm 159^{\mathrm{c}}$ & $762 \pm 161^{\mathrm{c}}$ & $-268 \pm 101^{\mathrm{f}}$ & $454 \pm 63^{\mathrm{a}, \mathrm{b}, \mathrm{c}}$ \\
At 306 & $813 \pm 58^{\mathrm{b}}$ & $587 \pm 63^{\mathrm{c}}$ & $1377 \pm 150^{\mathrm{b}}$ & $563 \pm 92^{\mathrm{b}, \mathrm{c}}$ & $263 \pm 66^{\mathrm{c}}$ \\
\hline
\end{tabular}

In each column means with same superscript are not significantly different $(\mathrm{p}<0.05)$

BU - Brabender Units, 1BU equivalent to 2.93 centipoises 
Table 4: Textural characteristics of cooked rice noodles

\begin{tabular}{lcccc}
\hline Variety & $\begin{array}{c}\text { Tensile } \\
\text { strength } \\
(\mathrm{g})\end{array}$ & $\begin{array}{c}\text { Extensibility } \\
(\mathrm{mm})\end{array}$ & $\begin{array}{c}\text { Elastic } \\
\text { recovery } \\
(\%)\end{array}$ & $\begin{array}{c}\text { Firmness } \\
(\%)\end{array}$ \\
\hline Bg 352 & $16.7 \pm 3.4^{\mathrm{a}}$ & $11.4 \pm 2.3^{\mathrm{a}}$ & $50.3 \pm 6.1^{\mathrm{a}}$ & $8.6 \pm 2.7^{\mathrm{a}}$ \\
Bg 300 & $13.2 \pm 3.8^{\mathrm{b}}$ & $11.8 \pm 2.5^{\mathrm{a}}$ & $46.6 \pm 8.2^{\mathrm{a}}$ & $87.9 \pm 2.4^{\mathrm{a}, \mathrm{b}}$ \\
Bg 403 & $12.2 \pm 2.3^{\mathrm{b}}$ & $11.8 \pm 2.1^{\mathrm{a}}$ & $37.3 \pm 9.0^{\mathrm{b}}$ & $85.8 \pm 3.9^{\mathrm{b}}$ \\
Bg 94-1 & $12.1 \pm 4.6^{\mathrm{b}}$ & $9.2 \pm 3.1^{\mathrm{b}}$ & $48.6 \pm 8.5^{\mathrm{a}}$ & $88.2 \pm 3.4^{\mathrm{a}, \mathrm{b}}$ \\
Ld 356 & $10.7 \pm 3.6^{\mathrm{b}, \mathrm{c}}$ & $10.2 \pm 2.6^{\mathrm{a}, \mathrm{b}}$ & $35.6 \pm 10.3^{\mathrm{b}}$ & $89.0 \pm 1.4^{\mathrm{a}}$ \\
Bw 272 6b & $11.9 \pm 3.3^{\mathrm{b}}$ & $10.3 \pm 1.5^{\mathrm{a}, \mathrm{b}}$ & $49.4 \pm 12.6^{\mathrm{a}}$ & $87.6 \pm 1.1^{\mathrm{a}, \mathrm{b}}$ \\
At 405 & $8.0 \pm 1.7^{\mathrm{c}}$ & $6.1 \pm 1.6^{\mathrm{c}}$ & $26.2 \pm 5.4^{\mathrm{c}}$ & $86.7 \pm 2.6^{\mathrm{a}, \mathrm{b}}$ \\
At 306 & $13.5 \pm 3.0^{\mathrm{b}}$ & $6.0 \pm 1.8^{\mathrm{c}}$ & $52.2 \pm 14.5^{\mathrm{a}}$ & $88.5 \pm 3.1^{\mathrm{a}}$
\end{tabular}

In each column values with same superscript are not significantly different $(p<0.05)$

Table 5: Sensory attributes of noodles prepared from different rice varieties

\begin{tabular}{lccccc}
\hline Variety & Appearance & Flavour & Hardness & Stickiness & $\begin{array}{c}\text { Overall } \\
\text { acceptability }\end{array}$ \\
\hline Bg 352 & $6.3^{\mathrm{a}, \mathrm{b}}$ & $5.4^{\mathrm{a}}$ & $5.7^{\mathrm{a}, \mathrm{b}}$ & $5.9^{\mathrm{a}}$ & $5.7^{\mathrm{a}, \mathrm{b}}$ \\
Bg 300 & $6.5^{\mathrm{a}}$ & $5.5^{\mathrm{a}}$ & $5.9^{\mathrm{a}}$ & $6.0^{\mathrm{a}}$ & $6.2^{\mathrm{a}}$ \\
Bg 403 & $6.1^{\mathrm{a}, \mathrm{b}, \mathrm{c}}$ & $5.5^{\mathrm{a}}$ & $5.3^{\mathrm{a}, \mathrm{b}}$ & $5.8^{\mathrm{a}}$ & $5.6^{\mathrm{a}, \mathrm{b}}$ \\
Bg 94-1 & $6.4^{\mathrm{a}}$ & $5.3^{\mathrm{a}}$ & $5.4^{\mathrm{a}, \mathrm{b}}$ & $5.6^{\mathrm{a}}$ & $5.5^{\mathrm{a}, \mathrm{b}}$ \\
Ld 356 & $5.9^{\mathrm{a}, \mathrm{b}, \mathrm{c}}$ & $5.5^{\mathrm{a}}$ & $5.6^{\mathrm{a}, \mathrm{b}}$ & $5.9^{\mathrm{a}}$ & $5.6^{\mathrm{a}, \mathrm{b}}$ \\
Bw 272-6b & $5.7^{\mathrm{b}, \mathrm{c}}$ & $5.3^{\mathrm{a}}$ & $5.7^{\mathrm{a}}$ & $5.7^{\mathrm{a}}$ & $5.5^{\mathrm{a}, \mathrm{b}}$ \\
At 405 & $3.5^{\mathrm{d}}$ & $5.5^{\mathrm{a}}$ & $3.1^{\mathrm{c}}$ & $2.1^{\mathrm{c}}$ & $2.7^{\mathrm{c}}$ \\
At 306 & $5.5^{\mathrm{c}}$ & $5.1^{\mathrm{a}}$ & $4.8^{\mathrm{b}}$ & $4.7^{\mathrm{b}}$ & $4.9^{\mathrm{b}}$ \\
\hline
\end{tabular}

In each column values with same superscript are not significantly different $(\mathrm{p}<0.05)$ seven point Hedonic scale

Table 6: Correlation between physicochemical properties of rice varieties and noodle quality

\begin{tabular}{|c|c|c|c|c|c|c|}
\hline \multirow{2}{*}{$\begin{array}{l}\text { Physicochemical } \\
\text { properties of rice }\end{array}$} & \multicolumn{6}{|c|}{ Noodle quality } \\
\hline & $\begin{array}{c}\text { Cooking } \\
\text { loss }\end{array}$ & $\begin{array}{l}\text { Swelling } \\
\text { ratio }\end{array}$ & $\begin{array}{l}\text { Elastic } \\
\text { recovery }\end{array}$ & Firmness & $\begin{array}{l}\text { Tensile } \\
\text { strength }\end{array}$ & Extensibility \\
\hline Amylose & $-0.802^{* * * *}$ & $0.809^{* * *}$ & $0.388^{*}$ & 0.082 & $0.403^{*}$ & $0.427^{*}$ \\
\hline Fat & -0.017 & 0.037 & 0.215 & 0.023 & -0.046 & -0.229 \\
\hline Protein & $0.367^{* *}$ & -0.071 & -0.026 & 0.231 & -0.085 & -0.184 \\
\hline Swelling volume & $0.479^{* *}$ & $-0.324^{*}$ & -0.198 & -0.066 & -0.255 & -0.238 \\
\hline Swelling power & 0.225 & 0.011 & 0.089 & 0.055 & -0.084 & 0.058 \\
\hline Solubility & -0.109 & 0.193 & 0.118 & 0.024 & 0.034 & 0.146 \\
\hline Peak viscosity & $-0.541^{* *}$ & 0.296 & 0.079 & 0.085 & 0.102 & 0.380 \\
\hline Hot paste viscosity & -0.182 & $0.402^{* *}$ & 0.239 & 0.188 & 0.189 & 0.286 \\
\hline Cold paste viscosity & $-0.399^{*}$ & $0.673^{* *}$ & $0.500^{*}$ & 0.181 & $0.460^{* *}$ & $0.424^{* *}$ \\
\hline Setback & -0.213 & $0.616^{* *}$ & $0.516^{* *}$ & 0.163 & $0.462^{* *}$ & $0.307^{*}$ \\
\hline Breakdown & $-0.374^{*}$ & -0.067 & -0.136 & -0.085 & -0.069 & 0.121 \\
\hline
\end{tabular}




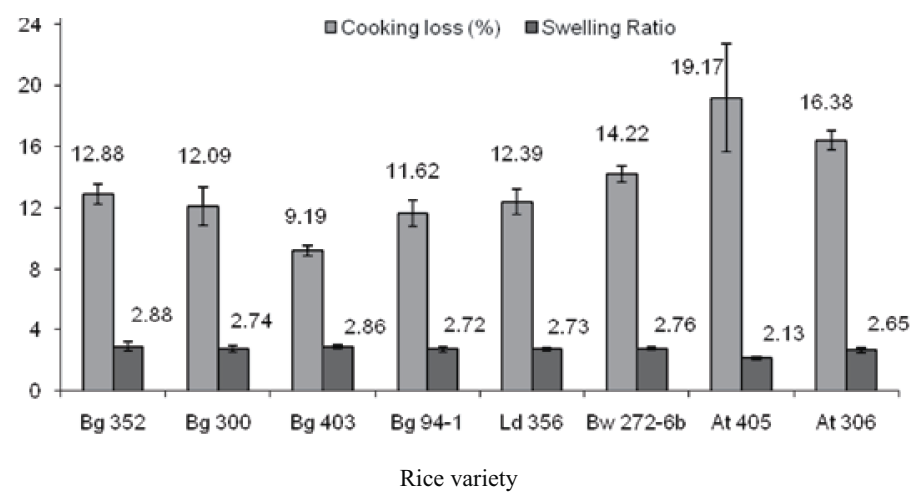

Figure 1: Cooking loss and swelling ratio of noodles prepared by different rice varieties

Breakdown viscosity (BD) is the measure of the susceptibility of cooked starch granules for disintegration, which is determined by the difference between PV and HPV (Sowbhagya \& Ali, 2001). Rice variety Bg 403 and Bg 94-1 had significantly higher values for BD. Setback (SB) viscosity is an essentially derived tool that describes the difference between CPV and HPV. SB value indicates the recovery of the viscosity during cooling of heated starch suspension (Sing et al., 2006). Lowest SB value for rice variety At 405 is an indication that this variety is softer after cooking. At 405 has shown a low value for HPV, CPV, SB and BD.

\section{Cooking quality of rice noodles}

Cooking loss and rehydration are important features for determining noodle quality. Rice noodles should have short cooking time with negligible loss of solids in cooking water. Low rehydration usually results in noodles with hard and coarse texture, but excess water uptake often results in soft and sticky noodles (Yoenyongbuddhagal \& Noomhorm, 2002).

All rice noodle samples showed an optimum cooking time of 5 minutes. Cooking quality characteristics of rice noodles is shown in Figure 1. Cooking loss was significantly different among the rice varieties and high in noodles made from At $405(19.17 \pm 3.50)$ while it was low in $\mathrm{Bg} 403$ (9.19 \pm 0.33$)$. All high amylose rice varieties had comparatively low cooking loss. High cooking loss is undesirable as it indicates high solubility of starch, resulting in turbid cooking water, low cooking and sticky mouth feel (Bhattacharya et al., 1999). Cooking loss correlated negatively with AC of rice $(r=-0.802$, $\mathrm{p}<0.001)$. Swelling ratio was significantly $(\mathrm{p}<0.05)$ low for At 405 (2.13 \pm 0.08$)$. There were no significant differences observed among the other varieties, which had comparatively similar values for rehydration.

\section{Textural properties of cooked rice noodles}

Texture of cooked noodles is the most critical characteristic, which determines consumer acceptance of the product. In this study, aspects of noodle texture were evaluated using tensile testing, elastic recovery and firmness (Table 4).

Tensile testing assesses the breaking strength and the breaking length of noodles. These properties correlated well with each other and it is an indication of how well the noodle strands resist breakdown (Seib et al., 2000). It also gives an indication on how the samples hold together during cooking and reflects the cooking tolerance and cooking quality of noodles (Bhattacharya et al., 1999). Tensile strength was significantly $(\mathrm{p}<0.05)$ high for Bg $352(16.7 \pm 3.4 \mathrm{~g})$ and significantly low for At 405 $(8.0 \pm 1.8 \mathrm{~g})$. Other varieties had comparable values for tensile strength. The distance to break the noodle strands is the measure for extensibility (Bhattacharya et al., 1999). The extensibility ranged from $6.0 \pm 1.8$ in At 306 to $11.8 \pm 2.5$ in $\mathrm{Bg} 300$. Noodles prepared from At 405 flour had the lowest tensil strength and required shorter time to break, which indicates low extensibility. Increased tensile strength and extensibility were found in noodles made from high amylose rice. The results indicated that noodles became more difficult to stretch and break with the increase of AC of rice. Tensile strength of noodles showed a positive correlation with $\mathrm{AC}(\mathrm{r}=0.403, \mathrm{p}<0.05)$.

The predominant characteristics of the quality of noodles related to textural characteristics such as translucency, colour, uniformity of appearance, mechanical strength and integrity, absence of sticky surface, which are characterized by firmness and elasticity (Sowbhagya \& Ali, 2001). Elastic recovery of noodles ranged from $26.2 \pm 5.4 \%$ in At 405 to $52.2 \pm 14.5 \%$ in 
At 306. Firmness of noodles ranged from $85.8 \pm 3.9 \%$ in $\mathrm{Bg} 403$ to $89.0 \pm 1.4 \%$ in $\mathrm{Ld} \mathrm{356}$. Noodles with higher firmness and elastic recovery can result in good quality noodles with low cooking loss (Chen et al., 2002).

\section{Sensory attributes of rice noodles}

The sensory attributes of rice noodles are given in Table 5. The appearance of rice noodles was significantly different amongst the noodles made out of different rice varieties. Noodles from rice variety At 405 and At 306 had a significantly $(\mathrm{p}<0.05)$ low value for appearance, and the appearance was disliked by most of the panellists. Noodles made from all $\mathrm{Bg}$ varieties had higher values for appearance and were accepted by most of the panellists. There was no significant $(\mathrm{p}<0.05)$ difference observed for the flavour of rice noodles. The flavour of cooked noodles is a minor quality attribute from the consumer point of view compared to other characteristics.

Hardness of rice noodles made out of $\mathrm{Bg}$ varieties was higher. Rice noodles made from $\mathrm{Bg} 300$ had significantly $(p<0.05)$ higher value for hardness and were preferred by most panellists. Hardness and stickiness of rice noodles made from At 405 were significantly lower and this type was less preferred by the panellists. The rice noodles made from At 405 were very sticky and adhesive and this could be the reason for lower preference by the panellists. The panellists preferred hardness and stickiness of rice noodles made from other rice varieties. Hardness and stickiness of rice noodles are attributes of amylose content.

Based on the scores for overall acceptability, rice noodles made from At 405 flour had the significantly $(p<0.05)$ lowest score and were disliked by most of the panellists. Rice noodles made from $\mathrm{Bg} 300$ flour had a significantly higher value. Results of the sensory attributes of rice noodles indicates that the panellists preferred less sticky rice noodles. The panellists preferred non sticky and hard noodles, irrespective of the flavour.

\section{Relationship between physicochemical properties of rice and quality characteristics of noodles made from different varieties of rice flour}

Correlation analyses between physicochemical properties of rice varieties and the corresponding noodle qualities were examined. Pearson correlation coefficients were summarized in Table 6.

The amylose content significantly correlated negatively with cooking loss $(\mathrm{r}=-0.802, \mathrm{p}<0.001)$ positively with swelling ratio $(\mathrm{r}=0.809, \mathrm{p}<0.001)$ of noodles. AC positively correlated significantly at $\mathrm{p}<0.05$ with tensile strength, extensibility and elastic recovery. Desirable quality characteristics of rice noodles were observed among noodles made from the local rice varieties with high $\mathrm{AC}$.

Fat content of the different varieties of rice did not have a significant effect on the rice noodle properties. A significant positive correlation was observed between protein content of rice and cooking loss in noodles. Flour solubility was expected to have a positive correlation with cooking loss as shown in studies of Yoenyong-buddhagal \& Noomhorm (2002). In the present study it was negative and not significant. Swelling power of rice flour had a very poor relationship to noodle characteristics and was not significant.

Amylograph peak viscosity showed a significant negative correlation with $(\mathrm{r}=-0.541, \mathrm{p}<0.01)$ cooking loss. HPV correlated negatively with cooking loss but was not significant. HPV showed a significant positive correlation with swelling power $(\mathrm{p}=0.402, \mathrm{p}<0.01)$. Positive correlation found between HPV textural parameters and PV with swelling ratio and extensibility of noodles was not significant. A high HPV generally represents low cooking loss and superior eating quality (Bhattacharya et al., 1999). Cold paste viscosity correlated negatively with the cooking loss $(\mathrm{r}=0.399, \mathrm{p}<0.05)$, and positively with rehydration $(\mathrm{r}=0.673, \mathrm{p}<0.01)$, elastic recovery $(\mathrm{r}=0.501, \mathrm{p}<0.01)$, tensile strength $(\mathrm{r}=0.460$, $\mathrm{p}<0.01)$ and extensibility $(\mathrm{r}=0.424, \mathrm{p}<0.01)$. Setback viscosity correlated positively with swelling power, elastic recovery, tensile strength and extensibility at $\mathrm{p}<0.01$. Breakdown correlated negatively with cooking loss.

\section{Acknowledgement}

The authors acknowledge the Rice Research \& Development Centres of the Department of Agriculture for supplying samples of rice for the study.

\section{Reference}

1. American Association of Cereal Chemists (AACC) (1995). Approved Methods of the AACC, (9 $9^{\text {th }}$ edition). American Association of Cereal Chemists, Minnesota, USA.

2. Bhattacharya M., Zee S.Y. \& Corke H. (1999). Physicochemical properties related to quality of rice noodles. Cereal Chemistry 76(6): 861-867.

3. Chen Z., Legger A., Hassen J.P.H., Schols H.A. \& Voragen A.G.J. (2002). Evaluation of starch noodles made from three typical Chinese sweet-potato starches. Journal of 
Food Science 67(9): 3342-3347.

4. Crosbie G.B., Lambe W.J., Tsutsui H. \& Gilmour R.F. (1992). Further evaluation of wheat flour swelling volume test for identifying wheats potentially suitable for Japanese noodle. Journal of Cereal Science 15(3): 271-280.

5. Department of Agriculture, Sri Lanka (DOASL) (2006). Agriculture Technologies. Available at http:// www.agridept.gov.lk/pagelinks.php? pagelink $=$ Recommended $\% 20$ Varieties $\% 20 \&$ heading $=$ Rice, Accessed 17 May 2009

6. Hormdok R. \& Noomhorm A. (2007). Hydrothermal treatments of rice starch for improvement of rice noodle quality. LWT-Food Science \& Technology 40: 1723-1731.

7. Juliano B.O. \& Sakurai J. (1985). Miscellaneous rice products. Rice Chemistry and Technology (ed. B.O. Juliano), pp. 443-524. American Association of Cereal Chemists, Minnesota, USA.

8. Juliano B.O., ed. (1985). Criteria and tests for rice grain qualities. Rice Chemistry and Technology, pp. 443-524. American Association of Cereal Chemists, Minnesota, USA.

9. Mendis A. (2007). Sri Lanka Grain and Feed Annual Report 2007, pp. 3-4. USDA Foreign Agricultural Service, Global Agricultural Information Network, Washington DC, USA.

10. Mestres C.P., Colonna P. \& Buleon A. (1988). Characteristics of starch network within rice flour noodles and mungbeen starch vermicelli. Journal of Food Science 53(6): 1809-1812.

11. Seib P.A., Liang X., Guan F., Liang F.T. \& Yang H.C. (2000). Comparison of Asian noodles from some hard white and hard red wheat flours. Cereal Chemistry 77(6): 816-822.

12. Shuey W.C. \& Tipples K.H., eds. (1994). The Amylograph Handbook, $3^{\text {rd }}$ edition. American Association of Cereal Chemists, Minnesota, USA.

13. Sing N., Kaur L., Sandhu K.S., Kaur J. \& Nishinari K. (2006). Relationship between physicochemical, morphological, thermal, rheological properties of rice starches. Food Hydrocolloids 20(4): 532-542.

14. Sowbhagya C.M. \& Ali S.K. (2001). Vermicelli noodles and their quality assessment. Journal of Food Science \& Technology 38(5): 423-432.

15. Sri Lankan Standards (SLS) 858 (1989). Specifications for Rice Noodles (Rice Vermicelli). Sri Lanka Standards Institution, Colombo 08.

16. Suhendro E.L., Kunetz C.F., McDonough C.M., Rooney L.W. \& Waniska R.D. (2000). Cooking characteristics and quality of noodles from sorghum. Cereal Chemistry 77(2): 96-100.

17. Wickramasinghe H.A.M. \& Nado T. (2008). Physicochemical properties of starches from Sri Lankan rice varieties. Food Science and Technology Research 14(1): 49-54.

18. Yoenyong-buddhagal S. \& Noomhorm A. (2002). Effect of raw material preparation on rice vermicelli quality. Starch 54(11): 534-539.

19. Zhou Z., Robards K., Heliwell S. \& Blanchard C. (2002). Compositional \& functional properties of rice. International Journal of Food Science \& Technology 37(8): 849-868 